\title{
Urban-rural differences in perception of trees described by parents bringing up children in Warsaw and Jedlińsk, Poland
}

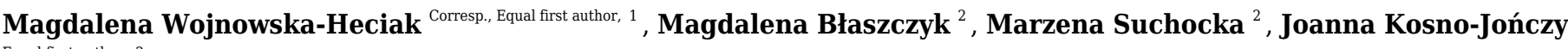 \\ Equal first author, 3 \\ ${ }^{1}$ Department of Civil Engineering and Architecture, Kielce University of Technology, Kielce, Poland \\ Department of Landscape Architecture, Institute of Environmental Engineering, Warsaw University of Life Sciences - SGGW, Warsaw, Poland \\ 3 Unaffiliated, Warsaw, Poland \\ Corresponding Author: Magdalena Wojnowska-Heciak \\ Email address: mwojnowska@tu.kielce.pl
}

Parents' attitudes to trees and nature are reflected not only in their children's outdoor activity, but also in the way they perceive, learn, and value the environment. One hundred and eleven respondents, divided into two groups by place of residence, assessed statements in a survey questionnaire. Two groups of questions aimed at evaluating tree benefits and disservices as perceived by urban and rural parents, and identifying their preferences concerning outdoor activity of their children. Tree benefits and disadvantages were grouped into 5 categories (social, economic, environmental, health, and aesthetic). Both urban and rural parents presented similar attitudes to trees as well as to their children's play environments. Among 37 statements concerning tree benefits, only 5 revealed statistically significant differences. The most important difference appeared in the way urban and rural parents perceived the aspects of danger. Trees were not perceived as posing any risk on playgrounds for city residents, who - unlike villagers opposed to the removal of trees from playgrounds. 
1 Urban-rural differences in perception of trees described 2 by parents bringing up children in Warsaw and Jedlińsk, 3 Poland

5 Magdalena Wojnowska-Heciak¹, Magdalena Błaszczyk², Marzena Suchocka ${ }^{2,}$ Joanna 6 Kosno-Jończy

$8{ }^{1}$ Department of Civil Engineering and Architecture, Kielce University of Technology, al. 9 Tysiąclecia Państwa Polskiego 7, 25-314 Kielce, Poland

102 Department of Landscape Architecture, Institute of Environmental Engineering, 11 Warsaw University of Life Sciences - SGGW, ul. Nowoursynowska 159, 02-776 Warsaw, 12 Poland

14 Corresponding Author:

15 Magdalena Wojnowska-Heciak

16 al. Tysiąclecia Państwa Polskiego 7, 25-314 Kielce, Poland

17 Email address: mwojnowska@poczta.tu.kielce.pl

\section{Abstract}

Parents' attitudes to trees and nature are reflected not only in their children's outdoor activity, but also in the way they perceive, learn, and value the environment. One hundred and eleven respondents, divided into two groups by place of residence, assessed statements in a survey questionnaire. Two groups of questions aimed at evaluating tree benefits and disservices as perceived by urban and rural parents, and identifying their preferences concerning the outdoor activity of their children. Tree benefits and disadvantages were grouped into 5 categories (social, economic, environmental, health, and aesthetic). Both urban and rural parents presented similar attitudes to trees as well as to their children's play environments. important difference appeared in the way urban and rural parents perceived the aspects of danger. Trees were not perceived as posing any risk on playgrounds for city residents, who - unlike villagers - opposed to the removal of trees from playgrounds.

Keywords: parents; attitudes towards trees; preference of trees; sociodemographic differences; social survey 


\section{Introduction}

39

The issue of children's development in today's booming world is complicated, especially in the context of the role of nature and trees for the proper development of children considering the reduced amount of time spent outdoor by the children nowadays. The study requires an analysis of the perception of services and disservices provided by trees in cities and in rural areas as perceived by adults who control children' timetables. Another issue is how the contact with nature influences children's development, especially in the context of differences between the current and previous generations. All these aspects, described in the literature review below, allowed us to build a coherent structure of our research.

Perception is the basic process of cognition. Ability to observe and receive stimuli from the environment enables people to function in it and allows them to get to know each other. The main channels through which raw information (sensations) reaches the human brain are the senses, of which sight, hearing and touch play the greatest role in spatial orientation. Vision, i.e., interpreted sensations, is a complex entity and best adapted to the perception of space of all senses [1]. In addition to spatial impressions, vision receives the time-related experience [2] and provides the ability to assess not only the physical properties of space (shapes, colours, light-shade systems), but also movement and change. Terms such as "perception", "sensual impression”, "experience”, and "cognition" describe ways or levels of learning and understanding space [3].

Trees play a huge role in the perception of space. They affect the senses both as a single element and a part of the landscape. Trees can be perceived in a variety of ways, depending on the place of birth, education, upbringing or views of the observer. For some people, they are a part of social and mental life. Others, however, are negatively minded, noticing mostly defects and threats from trees. Numerous studies have demonstrated that the presence of trees and urban nature can improve people's mental and physical health, children's attention and test scores, the property values in a neighbourhood and beyond. Trees cool our urban centres. Trees are essential for healthy communities and people [4].

\subsection{Perception of tree benefits and threats}


69

Positive perception of trees [5] and the benefits of their presence in a built environment [6] are verified in various types of surveys. This is reflected in the respondents' indications of a greater sense of security [7-12], energy savings for the building's cooling [13-19], improved microclimate of the city and mitigated heat island effect [20-25], along with reduced amount of carbon dioxide [18-19] rainfall runoff, noise levels and wind speed $[18,26]$. People associate relief from stress with being surrounded by nature [27-30]. The literature on environmental preference and restoration is guided also by Stress Recovery Theory from Ulrich (SRT) [31-32] and Attention Restoration Theory (ART) from Kaplan and Kaplan [33]. Visual and aesthetic values of trees are also highly appreciated [34]. Economic benefits of trees are well known, too. The presence of trees (especially big and mature ones) contributes to the increase of property value [3536]. Social and psychological benefits associated with trees and nature are also well recognized. Stronger sense of community and connection with other people, as well as increasing feeling of safety and enjoyment of everyday life is reported [26, 37-43].

Although tree benefits seem to be overwhelming [44], some tree related annoyance is also reported. Displeasure with messiness and clutter, nuisance caused by insects and animals, and allergies are among the reported inconveniences [45]. Complaints concern damage caused by tree roots lifting sidewalks and clogging underground pipes [46-47]. Trees can also trigger a sense of danger in case of defective branches or poor tree architecture. As the level of acceptable risk is rather low, trees are often felled, as a result of an unsubstantiated fear. Trees' conflict with the road infrastructure is one of the main reasons of felling trees in Poland, and law regulations seem to be the most efficient mean of tree protection [48-49]. In general, trees are perceived as a threat to traffic safety, especially by road authorities. Trees "killing the drivers" is a common picture presented to the public, also by the media. Tall, mature trees that block off light can also lead to the fear of crime [45]. Therefore, tree density is one of the factors influencing the sense of safety [50-51].

\subsection{The impact of nature perception on children's development}

Since the number of city dwellers increases, it is no surprise that most children play indoors. In several cities in England there are campaigns like Natural England that aim at doubling the number of farm visits by school children. Actions such as the launch of a new interactive website for families interested in wildlife encourage more children to visit 
103 national nature reserves and ensure more people from deprived communities gain access 104 to the natural world. The organisers of the campaigns claim that children are being 105 denied "the fundamental sense of independence and freedom in nature that their parents enjoyed and the natural environment is there to be explored by children"[52].

107 Richard Louv [53] observes that people love trees but limit children's contact with nature, instilling a kind of ecophobia in them. This results in 'nature deficit disorder' caused by alienation from the natural world. It is crucial not to shield children from outdoor adventures, which, as Louv believes, can be a preventive, additional, and in some cases an alternative cure for many diseases. A close relationship with nature can be

112 helpful in treating depression, mental problems and ADHD syndrome. Contact with 113 nature eliminates stress and increases self-esteem. In open spaces it is easier to establish 114 and deepen social ties. People who need time of "healthy" loneliness, in the bosom of 115 nature can calm down, relax, find an internal balance, nature gives solace, a feeling of 116 freedom and privacy, outdoor activity positively influences physical health, helps fight 117 obesity, respiratory diseases, sight and the backbone. Man strives for a connection with 118 nature through the desire for health, well-being, and greater efficiency [42, 54-56]. The 119 innate desire to come in contact with nature is called biophilia, a genetically coded basic 120 need for life [57]. Kellert et al. [2005] demonstrate that nature is important to children's 121 development in every major way - intellectually, emotionally, socially, spiritually, and 122 physically. Play in nature, particularly during middle childhood, is especially important 123 for developing the capacities for creativity, problem-solving, and emotional and 124 intellectual development [58-60].

125 There is some ambiguity in respondents' approach to the green public spaces. On the 126 one hand, people are willing to pay more for flats with a view (in Poland flats with a park 127 view are more expensive than those without it by ca. 6-10\%) [61], but on the other hand, 128 parents discourage children from playing in the open air for fear of getting dirty, having 129 ticks, risk from traffic or abduction and abuse. We are looking at an on-going national 130 movement away from nature-based recreation [62], for recreation in controlled 131 conditions on safety-tested prefabricated playground equipment [63]. However, free 132 outdoor play [64-65] is a prerequisite for proper development of the sense of 133 independence, decision-making abilities, resilience, and conflict resolution skills. As if we 134 forgot about our own parents' arguments: go and get some vitamin D from the sun - as 135 many children are vitamin D deficient [66]; move and burn some calories - as we observe 136 a growing number of overweight children and adolescents [66-68]; trees are good for you 
137

138

139

140

141

142

143

144

145

146

147

148

149

150

151

152

153

154

155

156

157

158

159

160

161

162

163

164

165

166

167

168

169

170

- as street trees may help prevent early childhood asthma [69]; get away from TV [70] so that you do not spoil your eyes [71] - considering that young children are growing up in a media-saturated environment; go outside and learn more about nature [72].

\subsection{Differences between urban and rural parents towards greenery}

In the metropolitan areas, the residents in general appreciated trees, but age, education, income, and perception of vegetation in general affect attitudes towards trees. The awareness that trees raise the value of property rises with age, education level and affluence of the respondents [73]. Citizens prefer trees near houses and liked both native and exotic tree species, but not those that dropped leaves or tended to fall. The studies show that people simultaneously agree that trees in urban areas cause damage (accidents, infrastructure damage) and offer a lot of benefits (oxygen supply, shade). Overall, respondents agree that there should be more trees in the cities [74]. Citizens also reveal a consumptive approach to greenery. They would like to benefit from nice views of nature and at the same time they do not want to take direct responsibility for the nature, start caring for the trees or bare costs for their maintenance [75].

Suburbs being 'half-world between city and country' [76] are expected to offer more green spaces and more trees, which may ensure a different perspective on trees. However, the study with suburban backyarders revealed varied opinions on trees in their backyards. For example, the balance between removal and aesthetics includes having to remove beautiful trees that died, as well as choosing to remove ugly ones. Similarly, the trade-off between tree removal and shade includes situations where people exhibited dubious attitudes. On the one hand, people opted for removing dangerous trees but felt bad about the loss of shade, on the other hand they wanted the trees removed for creating too much shade [77]. It seems that occupants of suburbs more often have even more ambivalent attitude towards trees than city residents. Another study concerning perception of trees by different suburb types within multiple towns, also showed that most respondents had positive perceptions about urban trees and attached a great deal of importance to those elements of the urban ecosystem [78].

There is evidence that farmers also have diverse attitudes towards trees growing at their private plots. Particularly strong are those views which reflect a lack of trust in the tree management agencies. This can be linked to a need for security, for people to feel safe in their backyards [79]. 
172 1.4. Childhood in the urban and rural area

173

174

175

176

177

178

179

180

181

182

183

184

185

186

187

188

189

190

191

192

193

194

195

196

197

198

199

200

201

202

203

The findings of comparative studies describing the childhood in the city and in the countryside, indicating that growing up in the countryside is healthier for children and more stimulating for their physical outdoor activity than living in the city, are not always so evident. The survey conducted on children (1687 boys; 1729 girls) recruited from fourth, fifth, and sixth grade classes in schools from urban areas, small cities, and rural areas shows obesity was higher among rural children $(25 \% ; \mathrm{P}<.001)$ than in children from urban areas (19\%) and small cities (17\%). Urban children were the least active (Cohens' $\mathrm{d}=-0.4$ ), particularly around lunchtime while at school ( $\mathrm{d}=-0.9$ to -1.1 ). Children from small cities exhibited the highest levels of physical activity [80].

A study aimed at examining physical activity in rural and urban neighbourhoods shows that urban adults took more steps a day and reported more walking and cycling for transport in the neighbourhood, more recreational walking in the neighbourhood, and more walking for transportation outside the neighbourhood than rural adults. Rural adults reported more recreational cycling in the neighbourhoods [81]. Therefore, city life not always means sedentary life in comparison to rural context. There is evidence that rural residents experience a health disadvantage compared to urban residents, associated with a greater prevalence of health risk factors and socioeconomic differences. Research in Canada identifies higher mortality rates, decreased life expectancy, greater incidence and prevalence of morbidity, and poorer self-reported health status in rural populations. For example, life expectancy at birth is at least 2 years less for men in rural areas compared to urban areas and the risks of death from circulatory disease or respiratory disease are as much as $10 \%$ higher in rural areas. This health disparity may be the result of different health risk factors, including health behaviours and socioeconomic status (SES). Additionally, different activity patterns between urban and rural populations may potentially lead to differences in exposure and risk(s) related to environmental contaminants, further contributing to the health disparity [82]. Daily activity patterns analysed in 2010 on young people shows that they get less than 60 minutes of daily moderate-to-vigorous physical activity (MVPA). Studies suggest that rural adults are less active than their urban counterparts, although studies of children are equivocal. The relationship between urban and rural residence and MVPA of young people appears to 
204 be more complex than previously envisioned. Rural residence appears to be supportive

205

206

207

208

209

210

211

212

213

214

215

216

217

218

219

220

221

222

223

224

225

226

227

228

229

230

231

232

233

234

235

236

237 of MVPA in girls but not boys [83].

In the survey conducted in Cyprus, parents of children in rural schools report more space available in the garden and in the neighbourhoods, and safer neighbourhoods than parents of children in urban schools, whereas children in urban schools have more exercise equipment available at home and are transported more frequently to places where they could be physically active [84]. There are also certain problems of growing up in the countryside. The survey conducted in rural Northamptonshire explores the ways in which children encounter the countryside through their own experiences, and (re)examine the 'rural' from their own viewpoint. The findings uncovered an alternative geography of exclusion and disenfranchisement. Rather than being part of an ideal community many children, especially the least affluent and teenagers, felt dislocated and detached from village life [85].

City children do not have ideal rates of physical activity. The study of 40 6- to 8-year-old Hong Kong children reveals that limited availability of outdoor play areas during the afternoon hours resulted in children spending $72.4 \%$ of their time sitting and lying down, being active only $10.4 \%$ of their time [86]. Time and frequency of playing outside were the significant correlates of physical activity in the studies of 4-year-old children [87-88]. Results show that $25 \%$ of the variance in physical activity was explained by demographic, social and environmental variables, and in the former study, gender, month and location (inside and outside the house) explained $75 \%$ of the variance in physical activity. Time spent outdoors and availability of space in the close distance are particularly important for younger children as they need to depend on other people for their transportation to places where they can be physically active. For example, Sallis et

al. [88-89] finds that parents transporting their children to exercise facilities were a variable significantly associated with physical activity.

\subsection{Differences between contemporary and previous generations}

There are many ways in which this generation's childhood is different from that of the last generation, but one of the most abrupt contrasts is the degree to which it is being spent indoors. There are lots of reasons, including the marked increase in time spend interacting with electronic devices, the emphasis on scheduled activities and achievements, concerns about sun exposure - and, for many families, the lack of safe 
238 outdoor places to play. It's not just children; adults are spending less time outdoors as 239 well [90]. However, children were found to spend less time playing outdoors than their mothers did when they were young - even in rural areas. According to a survey covering over 800 mothers, children in the early 2000s play less outdoors as compared to a generation ago when the mothers interviewed were children: $71 \%$ of today's mothers said they recalled playing outdoors every day as children, but only $26 \%$ of them said their kids play outdoors daily. A comparison between the children in the early 2000s and those a generation ago indicates clearly that they: 1) spend less time playing outdoors; 2) participate in different activities outdoors (e.g., fewer street games and more organized youth sports); and 3) participate in more indoor than outdoor play activities. When mothers were asked about obstacles to outdoor play and their thoughts regarding the benefits of outdoor play, almost all of them recognized some of the diverse benefits of outdoor play but also obstacles: such as television, computers, and concerns about crime, safety, and injury, prevented their children from participating in more outdoor play. The responses did not vary a great deal between mothers living in rural and urban areas. The results of that study negate the assumption that children living in rural areas would have access to greater public space for play and recreation. They find that farmlands, with their restricted use and lack of local supervision for children's activities, do not offer the rural child more opportunities for outdoor experiences [91].

\subsection{Aim of the Study}

259

The main aim of our research was to compare the attitudes towards trees of two groups of parents: the ones living in a city and those in the suburbs in a rural community in Poland. On the basis of the literature review and our own study, we aimed at understanding how urban and rural residents perceive tree benefits and tree threats, whether the place of residence impacts this perception, and how the parents' general perception of trees translates into their approach to children' play among trees.

\section{Materials and Methods}

268

269

2.1. Respondents

270 
271

272

273

274

275

276

277

278

279

280

281

282

283

284

285

286

287

288

289

290

291

292

293

294

295

296

297

298

299

300

301

302

303

304

The study was conducted with a sample survey of parents from two schools in the Mazowieckie Voivodship: Tadeusz Kościuszko Public Primary School in Jedlińsk (52 respondents) and Maria Kann Primary School No. 319 in Warsaw - Ursynów District (59 respondents). These are district public schools in which most of the children come from the closest vicinity. This feature allowed us to collect data from residents from one of the districts of the capital city of Poland (Warsaw) and residents of the suburbs of the medium-size city (Radom) in Poland, which in terms of administrative division is a rural community (Jedlińsk).

In 2018, there were 811 pupils in the primary school in Warsaw, including 363 pupils in 4-6 grade classes, and 450 pupils in the school in Jedlińsk, including 228 in 4-6 grades. The representative for the school sample of parents have children in 4 to 6 grades classes of primary schools (children aging from 10 to 12 years). The survey was conducted at the end of the teacher-parent meeting. Most of the respondents were women (80\%), probably because mainly women attend school meetings. With regard to the age criteria, people in the range of $30-45$ years $(72.1 \%$ ) dominated, $18.9 \%$ were under $30,7.2 \%$ in the age group $46-60$ and $1.8 \%$ over 60 years. Most of the respondents had a university degree $(60.4 \%), 35.1 \%$ completed secondary education and $4.5 \%$ only had elementary education. The ratio of people living in the countryside and in the city is 52 (46.8\%) to 59 (53.2\%). To be precise, 3 people living in the village come from a city, and 5 people living in the city come from a village. The survey included questions about the place of residence. Detailed sociodemographic characteristics of the respondents are presented in Table 1.

\section{Table 1. Sociodemographic characteristics of 111 parents participating in the survey.}

The study was performed with respect to the ethical principles of market research and public opinion as defined in the International Code of Market and Social Research, which was developed jointly by the European Association of Public Opinion and Market Researchers, the European Society for Opinion and Marketing Research (ESOMAR), and the International Chamber of Commerce (ICC). study also adheres to the Researchers Quality Control Program (PKJPA), which was developed and implemented in the Polish market by "Rynek" public opinion research organisation and adopted by Polish polling organisations.

The survey was performed as a voluntary anonymous questionnaire form given at the end of the parent-teacher meetings to parents. Respondents completed the 
305 questionnaire at school. The aim of the research was presented to the participants.

306 Returning completed forms was understood as a consent from the respondents to take

307 part in the research.

308

309

2.2. Questionnaire

310

311

312

313

314

315

316

317

318

319

320

321

322

323

324

325

326

327

Table 2. Benefits and disservices (problems, hazard costs and expenditur
divided into 5 categories (based on criteria presented by Roy et al. 2012).

The questionnaire used in the study was divided into four parts. The first group of questions (basic questions) was built on the principle of 37 sentences about mature trees. The responses were presented on a 7-point Likert scale (anchored by disagreement "definitely not" and agreement "absolutely yes") to assess the attitude to a given statement. The statements on benefits and disservices of trees were based on criteria presented by Roy et al. (2012) [92]. They were divided into 5 categories: social, economic, environmental, health, and aesthetic/visual (Table 2).

Table 2. Benefits and disservices (problems, hazard costs and expenditures) of trees

The second part consisted of 7 questions referring to preferences concerning trees and nature. The respondents were asked to assess whether the presence of trees was a significant criterion when choosing a place to live. They also assessed the quality of greenery around the place of residence, as well as the number of trees around it. One of the questions was on opinions regarding contact of children with trees. The respondents also stated their aesthetic preferences concerning plants in public spaces (deciduous trees, coniferous trees, shrubs, perennials and decorative grasses) (Table 3).

328 In the third group of statements the respondents revealed their attitudes towards tree management. Five statements were included in this part of the questionnaire. Respondents expressed their opinion on the law regarding tree logging, social responsibility for trees, and their own activities in designing green areas (e.g. through public consultations) (Table 4). In the second and third part of the survey the answers were marked on a 5- and 7-point Likert scale (statements regarding trees issues had a 7point scale, for greater accuracy, and the 5-point scale was adopted in questions regarding respondents' profile). In the last part of the questionnaire, the respondents provided information on their gender, age, education, place of birth and residence (village or city). Respondents were given the opportunity to state their opinion on trees and nature in general. Questionnaires were distributed to parents/guardians during parent-teacher meetings. The test took about 10 minutes and was anonymous. 
2.3. Data analysis

342

Several methods were used to analyse the results of the study: independence test $\chi 2$, analysis of the distribution of individual responses and their percentage ratio. The validity of choosing the independence test $\chi 2$ was confirmed by the diagram presented in the article of Watroba [93]. We compared 2 independent groups (village/city). We tested differences between nominal variables. The purpose of the test was to determine the relationship between two characteristics. Two hypotheses, $\mathrm{H} 0$ - variables $\mathrm{X}$ and $\mathrm{Y}$ are independent and H1 - variables $X$ and $Y$ are not independent, were formulated. The adopted level of significance (probability level) was $\alpha=0.05$. If $\mathrm{p}<\alpha, \mathrm{H} 0$ was rejected in favour of the alternative hypothesis. If $\mathrm{p} \geq \alpha$, there were no grounds to reject the $\mathrm{H} 0$ hypothesis. The p-value and the value of the $\chi 2$ test show the degree of dependence between two variables [94].

The test was performed using the RStudio Desktop and the $\mathrm{R}$ Commander (Rcmdr) package (Version 2.6.0) [95]. The report generated from RStudio allowed determining the relationships between the responses obtained from urban and rural residents.

\subsection{Study areas}

360

Warsaw is located on the Vistula River in east-central Poland. Its population is officially estimated at 1.78 million residents (on 517,24 sq. km) within a greater metropolitan area of 3.1 million residents, which makes Warsaw the biggest city in Poland and the 8th most populated capital city in the European Union [96-97]. According to the data published by TravelBird for 2018, the overall green space per inhabitant in the city of Warsaw was 109.45 square meters, with 41.98 square meters of forest and woodland per person (Table 3) [98].

Jedlińsk is a rural community functioning as suburbs of Radom, Poland. It is a historic settlement located $90 \mathrm{~km}$ south of Warsaw and $10 \mathrm{~km}$ north of Radom, on the Radomka and the Tymianka rivers. It had enjoyed town privileges for over 250 years until 1869 when it was transformed into a farming settlement. Today Jedlińsk has 1.700

372 inhabitants. The total area of the commune is 138.72 sq. km, and is inhabited by approx.

37314.400 people. The commune consists of 31 villages [99]. The overall green space per 
374 person in Jedlińsk was 107.54 square meters (Table 4) in 2018 with 74.96 square meters of 375 farmland per inhabitant. The comparison of the green space per inhabitant between 376 Warsaw and Jedlińsk (Table 3, Table 4) is surprising, as the area of forest per inhabitant 377 in Warsaw is almost four times the corresponding area in Jedlińsk. This indicates 378 potentially greater contact with clusters of trees in the city than in the rural commune. 379 The overall green space per resident is also higher in Warsaw than in Jedlińsk, although 380 the difference is not big.

381

Table 3. Green space in square meters per inhabitant in Warsaw [98]

383

Table 4. Green space in square meters per inhabitant in Jedlińsk [99]

385

386

\section{Results}

387

388

3.1. General perception of trees: benefits and disservices

389

390

391

392

393

394

395

396

397

398

399

400

401

402

403

404

405

406

407

Table 5. Differences in perception of social benefits and disservices of trees between rural and urban residents.

benefits. "Making urban environment more pleasant to live, work and spend leisure time" was highly assessed by residents of the city: almost 75\% of them chose the answer "absolutely yes". None of the city dwellers chose the answers "definitely not", and "no". Most people did not perceive trees as factors contributing to crime reduction or fear of crime.

\section{rural and urban residents.}

Almost all respondents agree that mature trees bring the world of nature closer to people. The most frequently indicated answers were: "absolutely yes" (city: 59.3\%, village: $36.5 \%$ ) and "yes" (city: 33.9\%, village: $48.1 \%$ ). In the group of economic statements statistically significant differences appeared among both benefits and disservices (Table 6). Unlike city dwellers, villagers think that trees reduce expenditure on road surface repairs. On the other hand, compared to rural residents, most parents living in the city do not agree with the statement that costs of maintaining mature trees 408 overwhelm their benefits. City inhabitants most often indicated the answer "not at all" $(33.9 \%)$ and "no" (27.1\%), while rural residents chose "rather not" (26.9\%) and "I do not 
409 know" (30.8\%). It turns out that city dwellers are less inclined to say that the cost of 410 maintaining the trees exceeds their benefits.

411

412 Table 6. Differences in perception of economic benefits and disservices between rural 413 and urban residents.

Table 7. Differences in perception of environmental benefits and disservices between rural and urban residents. again, only one of them showed a statistically significant difference between rural and urban parents (Table 7). Around 40\% of city dwellers did not perceive "dropping leaves" as annoyance, while $25 \%$ of villagers chose the answer "yes" when evaluating the statement.

Most respondents agree that mature trees create a favourable microclimate. The most frequently chosen answer was "absolutely yes" (city: 76.3\%, village: $44.2 \%$ ) and yes (city: 15.3\%, village: $42.3 \%$ ). Two people living in the countryside did not agree with it, and one had no opinion. The respondents agree with the statement that mature trees significantly improve air quality. Only 3 people had no opinion and one person did not agree. The most frequently chosen option was "Absolutely yes" (city: 62.7\%, village: $59.6 \%$ ). There are no significant differences in response behaviour and resident group. The majority of respondents do not feel the threat from trees with fragile branches. The

No differences between resident groups were found for the items in the category of health benefits and disservices (Table 8). Most respondents agree with the statement that the presence of trees has a soothing effect on nerves and stress $(67.8 \%$ of urban residents and $50.0 \%$ of rural residents). Both groups think that the presence of trees helps to create relaxed psychological states (55.8\% of villagers and 76.3 of city dwellers). In response to "increasing attack by associated insects", most respondents chose statements ranging from "rather no" to "rather yes". 
443 Table 8. Differences in perception of health benefits and disservices between rural 444 and urban residents.

445

446

448

449

450

451

452

453

454

455

456

457

458

459

460

461

462

463

464

465

466

467

468

469

470

471

472

473

474

475

476

Only one statement from the category of aesthetic disservices of trees was differently evaluated by urban and rural parents (Table 9). Almost $45 \%$ of city residents did not agree with the statement that trees "look ugly if not maintained". Less than $20 \%$ of villagers shared this opinion. Most of the respondents strongly appreciated benefits of trees such as: "looking beautiful while blooming" and "creating seasonal interest by highlighting seasonal changes".

\section{Table 9. Differences in perception of aesthetic/visual benefits and disservices between} rural and urban residents.

\subsection{Preferences towards outdoor activity of children}

The way parents perceive trees affects the outdoor activity of children [100]. And, at the same time, it is the surroundings that contribute to shaping us and our perception of the world [101]. All this seems particularly important when taking into account the undergoing degradation of the natural environment, decreasing number of trees in cities, and, most of all, the need to increase the environmental awareness among young generations. Therefore, attention the residents of Warsaw and Jedlińsk was brought to children's outdoor activities among the trees.

For most of the statements, the answers of city dwellers and villagers were similar (Table 10). In general, respondents believe that mature trees have a positive impact on the development of children. A small percentage of people have no opinion on the subject (village: $5.8 \%$, city: $6.8 \%$ ). Only one city resident disagrees with this opinion. Most of the respondents believe that mature trees cause allergies. Some people have no opinion on this subject (village: $26.9 \%$, city: $13.6 \%$ ) and others do not agree with this statement (15.4\% of rural residents and $30.6 \%$ of urban residents).

We found a nearly statistically significant difference between rural and urban parents' responses to the question "Do you try to protect children from trees? (prohibited tree climbing, touching rotten parts, playing with leaves, branches") amounted to 0.0504 , which means that the result is on the verge of a significant diference. The biggest differences between urban and rural parents with regard to responses to this question 
477 were found for the "totally no" option (village: 3.8\%, city: $23.7 \%$ ) and "yes" (village: $21.2 \%$, 478 city: $8.5 \%)$.

479

480

481

482

483

484

485

486

487

488

489

490

491

492

493

494

495

496

497

498

499

500

501

502

503

504

505

506

507

508

509

Table 10. Differences between urban and rural parents with regard to approaches to children's play in natural surroundings.

Rural parents stronger disagreed to the statement '[Trees are] causing danger on playgrounds' compared to urban parents (0.006). This indicates a statistically significant difference between urban and rural parents. The most frequently indicated response of the rural residents was "no" (30.8\%) and "rather no" (21.2\%), and "definitely not" (42.4\%) and "no" (28.8\%) among the urban residents. The results indicate that people living in the countryside feel a greater threat from trees on the playgrounds.

Most respondents agree that mature trees contribute to the improvement of the physical health of people (children). The most frequently chosen response was "absolutely yes" (city: 35.6\%, village: $36.5 \%$ ) and "yes" (city: 30.5\%, village: $32.7 \%$ ). Some people did not have an opinion on this subject (city: $6.8 \%$, village: $13.5 \%$ ). One inhabitant of the village and eight city residents disagreed with this opinion.

Both city residents and villagers ask for more trees, greenery, parks, forests. One respondent commented on the need to protect children from the trees because of sticky resin and ticks.

\section{Discussion}

The survey revealed that urban and rural parents had generally similar views on the presence of trees in the surroundings, the benefits they offer and threats they pose when managed improperly. The research showed that despite the threats that trees pose, they are an invaluable element of surrounding landscape. In three out of five categories of tree benefits and disservices only one statement was evaluated differently by urban and rural parents. Two statistically significant differences appeared in the economic category of statements, and none in the health category (however, the group consisted of three statements only). For most attitudes regarding trees, we did not find differences between urban and rural parents (Table 5-9). The same observation has been reported in other studies concerning similar issues [80-89]. 
The results obtained in the present survey confirmed that despite the dominating positive perception of trees, parents perceive certain threats or disservices resulting from

512 tree presence (Table 10). Our study showed that villagers are more concerned with

513 "protecting" children from trees (Table 10, question "Do you try to protect children from 514 trees? (a ban on tree climbing, touching rotten parts, playing with leaves, branches")).

515 Probably, parents' belief in deleterious impact of trees makes city and suburban children 516 spend less time playing outside than did children who were born a generation earlier. 517 This corresponds with the findings from other studies [90-91].

518 The results obtained in Warsaw and Jedlińsk show only few statistically significant 519 differences regarding the attitude towards trees (Table 10). City respondents more often 520 agreed to the statement that mature trees increase the comfort of staying in public places. 521 This may be due to the fact that the villagers living in suburban areas are assumed to 522 have more contact with vegetation and therefore cannot appreciate its presence to such a 523 great extent. Large discrepancies were found regarding the approach to old, damaged 524 trees. Most of the rural residents considered them as an unattractive element of the 525 landscape, whereas people living in cities did not share this opinion. Urban residents 526 have more positive attitudes towards trees, have higher appreciation for the benefits of 527 their presence, feel less threat from trees, and agree that mature trees increase the comfort 528 of visiting public places. They also pay more attention to the presence of trees when 529 choosing a place of residence. Rural residents more often believe that old, damaged trees 530 are visually unattractive. The results of this study clearly suggested that the absence of 531 trees near the residents' homes makes them feel deprived of natural environment and 532 makes them nostalgic for verdant neighbourhoods. It may be that villages have ceased to 533 be as natural as we imagine. It may also be that we all "come from the city" and Mother 534 Nature seems to intimidate us.

$535 \quad$ Rural parents feel greater danger posed by trees for their children than the city 536 residents (trees on playgrounds, climbing trees, playing with leaves and branches, etc.) 537 (Table 10). Against the background of the prevalence of attention deficit disorder and the 538 benefits that nature provides, the current concerns about barriers limiting children's 539 access to nature are not unfounded.

$540 \quad$ However, for most attitudes towards trees, we did not find significant differences 541 between urban and rural parents. Homogeneous results are probably influenced by a 542 similar structure of greenery of the selected settlement units (2.4. Study areas Table 3-4) 543 and the proximity of rural Jedlińsk to Radom. On the one hand, Warsaw has never had a 
544 compact city structure and included a patchwork of green open spaces. The Białowieża 545 forest and the semi-wild Vistula riverfront constitute the largest forested areas in Warsaw 546 and its surroundings. On the other hand, Jedlińsk is a very closely located suburb of the 547 city of Radom. This may facilitate the migration of people from the city to the immediate 548 vicinity and therefore urban living patterns are maintained. A similar behaviour of rural 549 and urban landscape planners with regard to trees means that the concept expressed in 550 Ildefonso Cerdá's General Theory of 'Urbanización' (making urban rural and rural urban) 551 has already materialized in some places. Perhaps a red lamp should light up for those 552 who deal with spatial planning in terms of further strong urbanization of suburban areas. 553 It seems that we have reached the point where both environments are similar or 554 homogeneous with respect to the structure of green areas (2.4. Study areas Table 3-4) and 555 the way the residents perceive their surrounding space (3. Results Table 5-9). The 556 557

558

559

560

561

562

563

564

565

566

567

568

569

570

571

572

573

574

575

576

577

578 sprawling urbanization process in suburban areas is visible in our social study.

\section{Conclusions}

The study should be extended to cover the male approach to raising children in the environment that includes trees, especially mature trees. Future research may select a sample which is representative with regard to gender. Maybe the issues of motherly fear for the safety of their offspring could been more balanced by the fathers' views.

The study results confirm that the urbanization is sprawling and the differences between urban and rural communities tend to diminish. The question is whether the number of trees and the general area of green public spaces will increase in the development plans for cities, suburbs and rural areas; whether the numerous theories about the benefits of trees in the environment, as reflected in the literature, will find practical application and we will see more trees in the neighbourhoods; what kind of new typologies of land development (urban and non-urban) structures will evolve in coming years; whether and how the new typologies would differ in terms of the amount and the layout of the green areas?

\section{Acknowledgments}

We thank Mrs. Izabela Konwerska-Barciak Principal of Maria Kann Primary School No. 319 in Warsaw and Mrs. Elżbieta Religa Principal of Tadeusz Kościuszko Public Primary School in Jedlińsk for support to our research. 


\section{References}

583 [1] Hatfield, G. Perception: History of the Concept. International Encyclopedia of the Social $584 \mathcal{E}$ Behavioral Sciences 2001, 11202-11205. https://doi.org/https://doi.org/10.1016/B0-08585 043076-7/00137-6.

586 [2] Klincewicz, M. Understanding Perception of Time in Terms of Perception of 587 Change. Procedia - Social and Behavioral Sciences 2014, 126, 58-63. 588 https://doi.org/https://doi.org/10.1016/j.sbspro.2014.02.315.

589 [3] Bernaciak, A. Percepcja Przestrzeni Miejskiej - Uczestnicy procesu i ich rola w 590 Przestrzeni. Turystyka i rekreacja miast i regionów 2014, 13-24.

591 [4] Turner-Skoff, J.; Cavender, N. The Benefits of Trees for Livable and Sustainable 592 Communities. Plants, People, Planet 2019, 1 (4). https://doi.org/10.1002/ppp3.39.

593 [6] Braverman, I. Everybody Loves Trees: Policing American Cities through Street Trees. 594 In Duke Environmental Law E Policy Forum; 2008; Vol. 19:81, pp. 81-118.

595 [7] Rae, R. A.; Simon, G.; Braden, J. Public Reactions to New Street Tree 596 Planting. CATE 3(1), 1-21. https://doi.org/10.15365/cate.31102010.

597 (8] Brunson, L. Resident Appropriation of Defensible Space in Public Housing: 598 Implicationsfor Safety and Community, Urbana-Champaign: University of Illinois, 1999. 599 [9] Kuo, F. E.; Bacaicoa, M.; Sullivan, W. C. Transforming Inner-City 600 Landscapes. Environment and Behavior 1998, 30 (1), 28-59. 601 https://doi.org/10.1177/0013916598301002.

602 [10] Schroeder, H. W.; Anderson, L. M. Perception of Personal Safety in Urban Recreation 603 Sites. Journal of Leisure Research 1985, 16, 178-194.

604 [11] Shaffer, G. S.; Anderson, L. M. Perceptions of the Security and Attractiveness of 605 Urban Parking Lots. Journal of Environmental Psychology 1985, 5, 311-323.

606 [12] Kuo, F.; Sullivan, W. Environment and Crime in the Inner City: Does Vegetation 607 Reduce Crime? 2001, 33 (3), 343-367. https://doi.org/10.1177/00139160121973025.

608 [13] Heisler, G. M. Energy Savings with Trees. Journal of Arboriculture 1986, 12, 113-125.

609 [14] Kaplan, S. Mental Fatigue and the Designed Environment. Public environments 1987, 610 55-60.

611 [15] Kirkpatrick, J. B.; Davison, A.; Daniels, G. D. Resident Attitudes towards Trees 612 Influence the Planting and Removal of Different Types of Trees in Eastern Australian 
613 Cities. Landscape and Urban Planning 2012, $107 \quad$ (2012), 147-158.

614 https://doi.org/10.1016/j.landurbplan.2012.05.015.

615 [16] Simpson, J. R. Improved Estimates of Tree-Shade Effects on Residential Energy

616 Use. Energy and Buildings 2002, 34 (10), 1067-1076. https://doi.org/10.1016/s0378-

617 7788(02)00028-2.

618 [17] Akbari, H.; Pomerantz, M.; Taha, H. Cool Surfaces and Shade Trees to Reduce Energy

619 Use and Improve Air Quality in Urban Areas. Solar Energy 2001, 70 (3), 295-310. 620 https://doi.org/10.1016/s0038-092x(00)00089-x.

621 [18] Nowak, D. J.; Dwyer, J. F. Understanding the Benefits and Costs of Urban Forest 622 Ecosystems. 2007, 25-46. https://doi.org/10.1007/978-1-4020-4289-8_2.

623 [19] Escobedo, F. J.; Kroeger, T.; Wagner, J. E. Urban Forests and Pollution Mitigation:

624 Analyzing Ecosystem Services and Disservices. Environmental Pollution 2011, 159 (8-9),

625 2078-2087. https://doi.org/10.1016/j.envpol.2011.01.010.

626 [20] Peper, P. J.; McPherson, E. G.; Simpson, J. R.; Albers, S. N.; Xiao, Q. Central Florida

627 Community Tree Guide: Benefits, Costs, and Strategic Planting. 2010.

628 https://doi.org/10.2737/psw-gtr-230.

629 [21] McPherson E. G. Chicago's Urban Forest Ecosystem: Results of the Chicago Urban Forests 630 Climate Project; 1993; pp. 115-135.

631 [22] Potchter, O.; Cohen, P.; Bitan, A. Climatic Behavior of Various Urban Parks during 632 Hot and Humid Summer in the Mediterranean City of Tel Aviv, Israel. Int. J. 633 Climatol.2006, 26 (12), 1695-1711. https://doi.org/10.1002/joc.1330.

634 [23] Bowler, D. E.; Buyung-Ali, L.; Knight, T. M.; Pullin, A. S. Urban Greening to Cool 635 Towns and Cities: A Systematic Review of the Empirical Evidence. Landscape and Urban 636 Planning 2010, 97 (3), 147-155. https://doi.org/10.1016/j.landurbplan.2010.05.006.

637 [24] Shashua-Bar, L.; Potchter, O.; Bitan, A.; Boltansky, D.; Yaakov, Y. Microclimate 638 Modelling of Street Tree Species Effects within the Varied Urban Morphology in the 639 Mediterranean City of Tel Aviv, Israel. Int. J. Climatol. 2009, n/a-n/a. 640 https://doi.org/10.1002/joc.1869.

641 [25] McCarthy, M. P.; Best, M. J.; Betts, R. A. Climate Change in Cities Due to Global 642 Warming and Urban Effects. Geophys. Res. Lett. 2010,37 (9), n/a-n/a. 643 https://doi.org/10.1029/2010g1042845.

644 [26] Tyrväinen, L.; Pauleit, S.; Seeland, K.; de Vries, S. Benefits and Uses of Urban Forests 645 and Trees. 2005, 81-114. https://doi.org/10.1007/3-540-27684-x_5. 
646 [27] Jiang, B.; Chang, C.-Y.; Sullivan, W. C. A Dose of Nature: Tree Cover, Stress 647 Reduction, and Gender Differences. Landscape and Urban Planning 2014, 132, 26-36. 648 https://doi.org/10.1016/j.landurbplan.2014.08.005.

649 [28] Jiang, B.; Li, D.; Larsen, L.; Sullivan, W. C. A Dose-Response Curve Describing the 650 Relationship Between Urban Tree Cover Density and Self-Reported Stress 651 Recovery. Environment and Behavior 2016, 48 (4), 607-629. 652 https://doi.org/10.1177/0013916514552321.

653 [29] van den Berg, A. E.; Jorgensen, A.; Wilson, E. R. Evaluating Restoration in Urban 654 Green Spaces: Does Setting Type Make a Difference? Landscape and Urban 655 Planning 2014, 127, 173-181. https://doi.org/10.1016/j.landurbplan.2014.04.012.

656 [30] Heinrichs, M.; Baumgartner, T.; Kirschbaum, C.; Ehlert, U. Social support and 657 oxytocin interact to suppress cortisol and subjective responses to psychosocial stress. Biol. 658 Psychiatry J. Soc. Biol. Psychiatry 2003, 54, 1389-1398

659 [31] Ulrich, R. S. Aesthetic and Affective Response to Natural Environment. 1983, 85-125. 660 https://doi.org/10.1007/978-1-4613-3539-9_4.

661 [32] Ulrich, R. S.; Simons, R. F.; Losito, B. D.; Fiorito, E.; Miles, M. A.; Zelson, M. Stress 662 Recovery During Exposure to Natural and Urban Environments. Journal of Environmental 663 Psychology 1991, 11 (3), 201-230. https://doi.org/10.1016/s0272-4944(05)80184-7.

664 [33] Kaplan, R.; Kaplan, S. The Experience of Nature; CUP Archive: Cambridge, 1989.

665 [34] Sudipto, R.J.; Pickering, B.C. A systematic quantitative review of urban tree benefits, 666 costs, and assessment methods across cities in different climatic zones. Urban For. Urban 667 Green. 2012, 11, 351-363.

668 [35] Ames, B.; Dewald, S. Working proactively with developers to preserve urban trees. 669 Cities 2003, 20, 95-100

670 [36] Wolch, J. R.; Byrne, J.; Newell, J. P. Urban Green Space, Public Health, and 671 Environmental Justice: The Challenge of Making Cities 'Just Green Enough.' Landscape 672 and Urban Planning 2014, 125, 234-244. https://doi.org/10.1016/j.landurbplan.2014.01.017. 673 [37] Bhatti, M.; Church, A. Home, the culture of nature and meanings of gardens in late 674 modernity. Hous. Stud. 2004, 19, 37-51

675 [38] Nilsson, K.; Sangster, M.; Konijnendijk, C. C. Forests, Trees and Human Health and 676 Well-Being: Introduction. 2011, 1-19. https://doi.org/10.1007/978-90-481-9806-1_1.

677 [39] de Vries, S.; Verheij, R. A.; Groenewegen, P. P.; Spreeuwenberg, P. Natural 678 Environments-Healthy Environments? An Exploratory Analysis of the Relationship 
679 between Greenspace and Health. Environ Plan A 2003, 35 (10), 1717-1731. 680 https://doi.org/10.1068/a35111.

681 [40] Taylor, M. S.; Wheeler, B. W.; White, M. P.; Economou, T.; Osborne, N. J. Research 682 Note: Urban Street Tree Density and Antidepressant Prescription Rates-A Cross683 Sectional Study in London, UK. Landscape and Urban Planning 2015, 136, 174-179. 684 https://doi.org/10.1016/j.landurbplan.2014.12.005.

685 [41] Korpela, K.; Borodulin, K.; Neuvonen, M.; Paronen, O.; Tyrväinen, L. Analyzing the 686 Mediators between Nature-Based Outdoor Recreation and Emotional Well-Being. Journal 687 of Environmental Psychology 2014, 37, 1-7. https://doi.org/10.1016/j.jenvp.2013.11.003.

688 [42] Nilsson, K.; Bentsen, P.; Grahn, P.; Mygind, L. De Quelles Preuves Scientifiques 689 Disposons-Nous Concernant Les Effets Des Forêts et Des Arbres Sur La Santé et Le Bien690 Être Humains? Rev. For. Fr. 2018, No. 2-3-4, 379. https://doi.org/10.4267/2042/70009.

691 [43] Kondo, M.; Fluehr, J.; McKeon, T.; Branas, C. Urban Green Space and Its Impact on 692 Human Health. IJERPH 15 (3), 445. https://doi.org/10.3390/ijerph15030445.

693 [44] Suchocka, M.; Jankowski, P.; Błaszczyk, M. Perception of Urban Trees by Polish Tree 694 Professionals vs. Nonprofessionals. Sustainability 2019a, 11, 211.

695 [45] Dwyer, J.; McPherson, E.G.; Schroeder, H.; Rowntree, R. Assessing the benefits and 696 costs of the urban forest. J. Arboric. 1992, 18, 227-234.

697 [46] Rolf, K.; Stal, Ö. Tree roots in sewer systems in Malmo, Sweden. J. Arboric. 1994, 20, 698 329-335. 37.

699 [47] Östberg, J.; Martinsson, M.; Stal, Ö.; Fransso, A. Risk of root intrusion by tree and 700 shrub species into sewer pipes in Swedish urban areas. Urban For. Urban Green. 2012, 11, $701 \quad 65-71$.

702 [48] Suchocka, M.; Błaszczyk, M.; Juźwiak, A.; Duriasz, J.; Bohdan, A.; Stolarczyk, J. 703 Transit versus Nature. Depreciation of Environmental Values of the Road Alleys. Case 704 Study: Gamerki-Jonkowo, Poland. Sustainability 2019b, 11, 1816.

705 [49] Suchocka, M.; Jankowski, P.; Błaszczyk, M. Tree protection on construction sites 706 Knowledge and perception of Polish professionals. Urban Forestry and Urban Greening 707 2019c, Vol. 46, 126436.

708 [50] Kuo, F.E.; Bacaioca, M.; Sullivan, W.C. Transforming inner city landscapes: Trees, 709 sense of safety, and preferences. Environ. Behav. 1998, 30, $28-59$.

710 [51] Kuo, F.E.; Sullivan, W.C. Aggression and violence in the inner city: Impacts of the 711 environment via mental fatigue. Environ. Behav. 2001, 33, 543-571. 
712 [52] Gray, L. 'Cottonwool Kids' Denied Access To Countryside, Warns Natural England 713 https://www.telegraph.co.uk/news/health/news/5089583/Cottonwool-kids-denied-

714 access-to-countryside-warns-Natural-England.html (accessed Nov 12, 2019).

715 [53] Louv, R. Last Child in the Woods; Atlantic Books Ltd, 2013.

716 [54] Maas, J.; Verheij, R. A.; de Vries, S.; Spreeuwenberg, P.; Schellevis, F. G.;

717 Groenewegen, P. P. Morbidity Is Related to a Green Living Environment. Journal of

718 Epidemiology $\mathcal{E} \quad$ Community Health 2009, 63 (12), 967-973.

719 https://doi.org/10.1136/jech.2008.079038.

720 [55]-Donovan, G. H.; Michael, Y. L.; Butry, D. T.; Sullivan, A. D.; Chase, J. M. Urban Trees

721 and the Risk of Poor Birth Outcomes. Health \& Place 2011, 17 (1), 390-393.

722 https://doi.org/10.1016/j.healthplace.2010.11.004.

723 [56] Turner-Skoff, J. B.; Cavender, N. The Benefits of Trees for Livable and Sustainable 724 Communities. Plants People Planet 2019, 1 (4), 323-335. https://doi.org/10.1002/ppp3.39.

725 [57] Modrzewski, B.; Szkołut, A. Biofilia - Teoria I Praktyka Projektowa. In Biocity; 726 Fundacja Wydziału Architektury Politechniki Warszawskiej: Warsaw, 2015; pp. 181-185.

727 [58] Kellert, S.R. Nature and Childhood Development. Building for Life: Designing and 728 Understanding the Human-Nature Connection 2005.

729 [59] Peper, P. J.; McPherson, E. G.; Simpson, J. R.; Gardner, S. L.; Vargas, K. E.; Xiao, 730 Q. New York Municipal Forest Resource Analysis; New York, 2007.

731 [60] Children's Health and the Environment. Action in Partnership. EOR/ICP/EHCO 0202 732 05/16 04279; WHO, Ed.; Regional Office for Europe, 1999.

733 [61] Rostkowska, K. Za Mieszkania Z Widokiem płaci Się więcej. Porównaliśmy Ceny. 734 January 1, 2018.

735 [62] Nader, P. R. Moderate-to-Vigorous Physical Activity from Ages 9 to 15 Years. JAMA 736 2008, 300 (3), 295. https://doi.org/10.1001/jama.300.3.295.

737 [63] Pergams, O. R. W.; Zaradic, P. A. Evidence for a Fundamental and Pervasive Shift 738 Away from Nature-Based Recreation. Proceedings of the National Academy of 739 Sciences 2008, 105 (7), 2295-2300. https://doi.org/10.1073/pnas.0709893105.

740 [64] Ginsburg, K. R. The Importance of Play in Promoting Healthy Child Development 741 and Maintaining Strong Parent-Child Bonds. PEDIATRICS 2007, 119 (1), 182-191. 742 https://doi.org/10.1542/peds.2006-2697.

743 [65] Lester, S.; Maudsley, M. Play, Naturally: A Review of children's Natural Play; Children's 744 Play Council, 2006. 
745 [66] Huh, S. Y.; Gordon, C. M. Vitamin D Deficiency in Children and Adolescents: 746 Epidemiology, Impact and Treatment. Reviews in Endocrine $\mathcal{E}$ Metabolic Disorders $747 \quad 2008,9(2), 161-170$.

748 [67] Ogden, C. L.; Caroll, M. D.; Flegal, K. M. High Body Mass Index for Age Among U.S. 749 Children and Adolescents, 2003-2006. Jama-Journal of The American Medical 750 Association 2008, 299(20), 2401-2405.

751 [68] Troiano, R. P.; Flegal, K. M.; Kuczmarski, R. J.; Campbell, S. M.; Johnson, C. L. 752 Overweight Prevalence and Trends for Children and Adolescents: The National-Health 753 and Nutrition Examination Surveys, 1963 to 1991. Archives of Pediatrics \& Adolescent 754 Medicine 1995, 149(10), 1085- 1091.

755 [69] Ogden, C. L.; Caroll, M. D.; Curtin, L. R.; McDowell, M. A.; Tabak, C. J.; Flegal, K. 756 M. Prevalence of Overweight and Obesity in the United States, 1999-2004. Jama-Journal of 757 the American Medical Association 2006, 295(13), 1549-1555.

758 [69] Lovasi, G. S.; Quinn, J.; Neckerman, K. M.; Perzanowski, M. S.; Rundle, A. Children 759 Living in Areas with More Street Trees Have Lower Prevalence of Asthma. Journal of 760 Epidemiology and Community Health 2008, 62(7), 647-649.

761 [70] Vandewater, E. A.; Rideout, V. J.; Wartella, E. A.; Huang, X.; Lee, J. H.; Shim, M. S. 762 Digital Childhood: Electronic Media and Technology Use Among Infants, Toddlers, and 763 Preschoolers. Pediatrics 2007, 119(5), E1006-E1015.

764 [71] Rose, K. A.; Morgan, I. G.; Ip, J.; Kifley, A.; Huynh, S.; Smith, W.; Mitchell, P. Outdoor 765 Activity Reduces the Prevalence of Myopia in Children. Ophthalmology 2008, 115 (8), 766 1279-1285. https://doi.org/10.1016/j.ophtha.2007.12.019.

767 [72] Bebbington, A. The Ability of A-Level Students to Name Plants. Journal of Biological 768 Education 2005, 39 (2), 63-67. https://doi.org/10.1080/00219266.2005.9655963.

769 [73] Shirazi, S. A.; Kazmi, J. H. Analysis of Socio-Environmental Impacts of the Loss of 770 Urban Trees and Vegetation in Lahore, Pakistan: A Review of Public Perception. Ecol 771 Process 2016, 5(1). https://doi.org/10.1186/s13717-016-0050-8.

772 [74] Camacho-Cervantes, M.; Schondube, J. E.; Castillo, A.; MacGregor-Fors, I. How Do 773 People Perceive Urban Trees? Assessing Likes and Dislikes in Relation to the Trees of a 774 City. Urban Ecosyst 2014, 17 (3), 761-773. https://doi.org/10.1007/s11252-014-0343-6.

775 [75] Wojnowska-Heciak, M. The Naturalness of the Vistula Riverbank's Landscape: 776 Warsaw Inhabitants' Perceptions. Sustainability $2019 \quad 11(21), \quad 5957$. 777 https://doi.org/10.3390/su11215957. 
778 [76] Boyd, R. Australia's Home. Why Australians Built the Way They Did.; Penguin: 779 Harmondsworth, 1952.

780 [77] Head, L.M.; Muir, P.; Bolton, G.; Dargavel; Gaynor, A.; Horwitz, P.; Mills, J.; Wardell781 Johnson, G. Living with Trees - Perspectives from the Suburbs. In Proceedings 6 th National 782 Conference of the Australian Forest History Society; Calvert, M., Bigler-Cole, H., Eds.; 783 Millpress: Rotterdam, 2005; pp 84-94.

784 [78] Gwedla, N.; Shackleton, C. M. Perceptions and Preferences for Urban Trees across 785 Multiple Socio-Economic Contexts in the Eastern Cape, South Africa. Landscape and Urban 786 Planning 2019, 189, 225-234.

787 [79] Zubair, M.; Garforth, C. Farm Level Tree Planting in Pakistan: The Role of Farmers' 788 Perceptions and Attitudes. Agroforest Syst 2006, 66 (3), 217-229. 789 https://doi.org/10.1007/s10457-005-8846-z.

790 [80] Joens-Matre, R. R.; Welk, G. J.; Calabro, M. A.; Russell, D. W.; Nicklay, E.; Hensley, 791 L. D. Rural-Urban Differences in Physical Activity, Physical Fitness, and Overweight 792 Prevalence of Children. J Rural Health 2008, 24 (1), 49-54. https://doi.org/10.1111/j.1748793 0361.2008.00136.x.

794 [81] Dyck, D. V.; Cardon, G.; Deforche, B.; De Bourdeaudhuij, I. Urban-Rural Differences 795 in Physical Activity in Belgian Adults and the Importance of Psychosocial Factors. J Urban 796 Health 2011, 88 (1), 154-167. https://doi.org/10.1007/s11524-010-9536-3.

797 [82] Matz, C. J.; Stieb, D. M.; Brion, O. Urban-Rural Differences in Daily Time-Activity 798 Patterns, Occupational Activity and Housing Characteristics. Environ Health 2015, 14 (1). 799 https://doi.org/10.1186/s12940-015-0075-y.

800 [83] Moore, J. B.; Beets, M. W.; Morris, S. F.; Kolbe, M. B. Comparison of Objectively 801 Measured Physical Activity Levels of Rural, Suburban, and Urban Youth. American 802 Journal of Preventive $\quad$ Medicine 2014, 46 (3), $\quad 289-292$. 803 https://doi.org/10.1016/j.amepre.2013.11.001.

804 [84] Loucaides, C. A. Differences in Physical Activity Levels between Urban and Rural 805 School Children in Cyprus. Health Education Research 2004, 19 (2), 138-147. 806 https://doi.org/10.1093/her/cyg014.

807 [85] Matthews, H.; Taylor, M.; Sherwood, K.; Tucker, F.; Melanie Limb. Growing-up in 808 the Countryside: Children and the Rural Idyll. Journal of Rural Studies 2000, 16 (2), 141809 153. https://doi.org/10.1016/s0743-0167(99)00059-5. 
810 [86] Johns, D. P.; Ha, A. S. Home and Recess Physical Activity of Hong Kong 811 Children. Research Quarterly for Exercise and Sport 1999, 70 (3), 319-323.

812 https://doi.org/10.1080/02701367.1999.10608051.

813 [87] Baranowski, T.; Thompson, W. O.; Durant, R. H.; Baranowski, J.; Puhl, J. 814 Observations on Physical Activity in Physical Locations: Ager Gender, Ethnicity, and 815 Month Effects. Research Quarterly for Exercise and Sport 1993, 64 (2), 127-133. 816 https://doi.org/10.1080/02701367.1993.10608789.

817 [88] Sallis, J. F. Physical Activity and Behavioral Medicine; SAGE Publications, 1998.

818 [89] Sallis, J.; Conway, T.; McKenzie, T.; Marshall, S.; Brown, M. He Association of School 819 Environments with Youth Physical Activity. Am J Public Health 2001, No. 91, 618-620. 820 https://doi.org/10.2105/ajph.91.4.618.

821 [90] McCarthy, C. 6 Reasons Children Need to Play Outside - Harvard Health Blog 822 https://www.health.harvard.edu/blog/6-reasons-children-need-to-play-outside-

8232018052213880 (accessed Nov 12, 2019).

824 [91] Clements, R. An Investigation of the State of Outdoor Play. Contemporary Issues in 825 Early Childhood. January 1, 2004, pp. 68-80.

826 [92] Roy, S.; Byrne, J.; Pickering, C. A systematic quantitative review of urban tree 827 benefits, costs, and assessment methods across cities in different climatic zones. Urban 828 Forestry and Urban Greening 2012, 11(4):351-363.

829 [93] Wątroba, J. Wspomaganie statystycznej analizy wyników badań empirycznych 830 file:///C:/Users/kosno/Downloads/Wspomaganie_stat_analizy_wynikow\%20(1).pdf

831 (accessed Jun.13, 2019).

832 [94] Górniak, J.; Wachnicki, J. Pierwsze Kroki W Analizie Danych; SPSS: Kraków, 2004.

833 [95] Fox, J. The R Commander: A Basic Statistics Graphical User Interface to R. Journal of 834 Statistical Software, 2005 14(9): 1-42.

835 [96] Warsaw https://en.m.wikipedia.org > wiki > Warsaw (accessed Nov 12, 2019).

836 [97] World Cities http://worldpopulationreview.com/world-cities/warsaw-population/ 837 (accessed Nov 12, 2019).

838 [98] Green Areas Per Inhabitant in Warsaw, Poland 2018 । Statista 839 https://www.statista.com/statistics/860478/green-areas-per-inhabitant-in-warsaw-

840 poland/ (accessed Nov 12, 2019).

841 [99] Gmina Jedlińsk http://jedlinsk.pl/56,o-gminie.html (accessed Nov 12, 2019

842 [100] Tappe, K. A.; Glanz, K.; Sallis, J. F.; Zhou, C.; Saelens, B. E. Children's Physical 843 Activity and Parents' Perception of the Neighborhood Environment: Neighborhood 
844 Impact on Kids Study. Int J Behav Nutr Phys Act 2013,10(1), 39.

845 https://doi.org/10.1186/1479-5868-10-39.

846 [101] Ellard, C. Places of the Heart; Bellevue Literary Press, 2015.

847 
Table $\mathbf{1}$ (on next page)

Table 1. 
1 Table 1. Sociodemographic characteristics of $\mathbf{1 1 1}$ parents participating in the survey. 2

\begin{tabular}{clllllll}
\hline \multirow{3}{*}{ Sex } & & $N$ & $\%$ & & & $n$ & $\%$ \\
\hline \multirow{4}{*}{ Age } & Male & 22 & 20 & Education & Elementary & 5 & 5 \\
& Female & 89 & 80 & & Secondary & 39 & 35 \\
& Below 30 & 21 & 19 & & Higher & 67 & 60 \\
& $30-45$ & 78 & 70 & Place of living & Village & 52 & 67 \\
& $46-60$ & 10 & 9 & & City & 59 & 53 \\
& Over 60 & 2 & 2 & Place of birth & Village & 54 & 49 \\
& & & & & City & 57 & 51 \\
\hline
\end{tabular}

3 
Table 2 (on next page)

Table 2. 


\section{Table 2. Benefits and disservices (problems, hazard costs and expenditures) of trees}

2 divided into 5 categories (based on criteria presented by Roy et al. 2012).

3

\begin{tabular}{|c|c|c|c|c|c|}
\hline & Social & Economic & Environmental & Health & $\begin{array}{r}\text { Aesthetic/ } \\
\text { Visual }\end{array}$ \\
\hline \multicolumn{6}{|l|}{ Benefits } \\
\hline \multicolumn{6}{|l|}{ work and spend leisure time } \\
\hline Increasing social cohesion & + & & & & \\
\hline Reducing crime & + & & & & \\
\hline Providing nature in the city & + & & & & \\
\hline Reducing speed (drivers are more careful) & + & & & & \\
\hline Savings on electricity costs & & + & & & \\
\hline Increasing property/land value & & + & & & \\
\hline Contributing to the economic vitality of the city & & + & & & \\
\hline Reducing expenditure on road surface repairs & & + & & & \\
\hline Modifying microclimate & & & + & & \\
\hline Improving air quality & & & + & & \\
\hline Reducing rate of storm water runoff & & & + & & \\
\hline Controlling wind & & & + & & \\
\hline Reducing solar radiation in summer & & & + & & \\
\hline Providing shade on sunny days & & & + & & \\
\hline Providing habitat for wildlife & & & + & & \\
\hline Reducing noise & & & + & & \\
\hline Creating relaxed psychological states & & & & + & \\
\hline Reducing stress & & & & + & \\
\hline Looking beautiful while blooming & & & & & + \\
\hline Improving scenic quality & & & & & + \\
\hline Providing privacy & & & & & + \\
\hline Creating seasonal interest by highlighting & & & & & + \\
\hline \multicolumn{6}{|l|}{ seasonal changes } \\
\hline Cover unpleasant views & & & & & + \\
\hline \multicolumn{6}{|l|}{ Disservices (problems, hazard costs and expenditures) } \\
\hline Causing fear of crime & + & & & & \\
\hline Contributing to road accidents & + & & & & \\
\hline Causing danger on playgrounds & + & & & & \\
\hline \multicolumn{6}{|l|}{ their benefits } \\
\hline Destroying road surface by roots & & + & & & \\
\hline Dropping flowers & & & + & & \\
\hline Dropping leaves & & & + & & \\
\hline Dropping branches and seeds & & & + & & \\
\hline Increasing attack by associated insects & & & & + & \\
\hline Drip sap or sticky residue on parked & & & & & + \\
\hline \multicolumn{6}{|l|}{ Cars } \\
\hline Obscuring good views & & & & & + \\
\hline Causing darkness & & & & & + \\
\hline Look ugly if not maintained & & & & & + \\
\hline
\end{tabular}


Table 3 (on next page)

Table 3. 
1 Table 3. Green space in square meters per inhabitant in Warsaw [97]

2

\begin{tabular}{|c|c|}
\hline Land use type in Warsaw & Square meters per inhabitant in Warsaw \\
\hline Forest and Woodland & 41.98 \\
\hline Farmland & 22.07 \\
\hline Nature Reserve & 19.76 \\
\hline Maintained Grass & 15.84 \\
\hline Park & 8.32 \\
\hline Public Garden & 0.61 \\
\hline Orchard & 0.36 \\
\hline Golf Course & 0.04 \\
\hline
\end{tabular}

3

4 
Table 4 (on next page)

Table 4. 
1 Table 4. Green space in square meters per inhabitant in Jedlińsk [98]

2

\begin{tabular}{l|c}
\hline Land use type in Jedlińsk & Square meters per inhabitant in Jedlińsk \\
\hline Farmland & 74.96 \\
Meadows & 11.7 \\
Forests & 11.34 \\
Pasture & 6.9 \\
Orchards & 2.64 \\
\hline
\end{tabular}

3 


\section{Table 5(on next page)}

Table 5. 


\section{Table 5. Differences in perception of social benefits and disservices of trees between 2 rural and urban residents.}

3

$\begin{array}{lllllllll}\text { Definitely } & \text { No } & \text { Rather } & \text { Do not } & \text { Rather } & \text { Yes } & \text { Absolutely } & & \\ \text { not }(\%) & (\%) & \text { no } & \text { know } & \text { yes } & (\%) & \text { yes } & \chi 2 & \text { p-value } \\ & & (\%) & (\%) & (\%) & & (\%) & & \end{array}$

\begin{tabular}{|c|c|c|c|c|c|c|c|c|c|c|}
\hline Benefits & & & & & & & & & & \\
\hline \multirow{2}{*}{$\begin{array}{l}\text { Making urbanized } \\
\text { environment* more pleasant } \\
\text { to live, work and spend }\end{array}$} & village & 1.9 & 1.9 & 0 & 0 & 13.5 & 36.5 & 46.2 & 19. & \multirow[b]{2}{*}{0.004} \\
\hline & city & 0 & 0 & 1.7 & 3.4 & 0 & 20.3 & 74.6 & $\begin{array}{l}19 . \\
098\end{array}$ & \\
\hline \multirow{2}{*}{$\begin{array}{l}\text { Building stronger sense of } \\
\text { community }\end{array}$} & village & 0 & 5.8 & 9.6 & 50.0 & 9.6 & 13.5 & 11.5 & 4.3 & \multirow{2}{*}{0.629} \\
\hline & city & 5.1 & 5.1 & 11.9 & 42.4 & 10.2 & 8.5 & 16.9 & 53 & \\
\hline \multirow[t]{2}{*}{ Reducing crime } & village & 17.3 & 7.7 & 13.5 & 57.7 & 1.9 & 1.9 & 0 & 4.7 & \multirow{2}{*}{0.579} \\
\hline & city & 23.7 & 10.2 & 5.1 & 54.2 & 1.7 & 1.7 & 3.4 & 29 & \\
\hline \multirow[t]{2}{*}{ Providing nature in the city } & village & 0 & 0 & 0 & 5.8 & 9.6 & 48.1 & 36.5 & 3.4 & \multirow{2}{*}{0.179} \\
\hline & city & 0 & 0 & 0 & 0 & 6.8 & 33.9 & 59.3 & 37 & \\
\hline \multirow{2}{*}{$\begin{array}{l}\text { Reducing speed (drivers are } \\
\text { more careful) }\end{array}$} & village & 1.9 & 5.8 & 7.7 & 25.0 & 32.7 & 23.1 & 3.8 & 9.2 & \multirow{2}{*}{0.161} \\
\hline & city & 8.5 & 5.1 & 18.6 & 23.7 & 20.3 & 13.6 & 10.2 & 28 & \\
\hline \multicolumn{11}{|c|}{ Disservices (problems, hazard costs and expenditures) } \\
\hline \multirow[t]{2}{*}{ Causing fear of crime } & village & 13.5 & 7.7 & 23.1 & 46.2 & 3.8 & 3.8 & 1.9 & 4.7 & \multirow{2}{*}{0.575} \\
\hline & city & 11.9 & 13.6 & 23.7 & 32.2 & 11.9 & 3.4 & 3.4 & 57 & \\
\hline \multirow{2}{*}{$\begin{array}{l}\text { Contributing } \\
\text { accidents }\end{array}$} & village & 17.3 & 15.4 & 34.6 & 5.8 & 17.3 & 9.6 & 0 & 5.3 & \multirow{2}{*}{0.496} \\
\hline & city & 23.7 & 16.9 & 33.9 & 8.5 & 10.2 & 3.4 & 3.4 & 80 & \\
\hline
\end{tabular}

4 Key: *Urbanized environment meaning public spaces or common spaces that have features of build-up areas that can be found in the

5 city, in the suburbs or in the countryside.

6 
Table 6(on next page)

Table 6. 


\section{Table 6. Differences in perception of economic benefits and disservices between rural} 2 and urban residents.

3

\begin{tabular}{|c|c|c|c|c|c|c|c|c|c|c|}
\hline & & $\begin{array}{l}\text { Definitely } \\
\text { not }(\%)\end{array}$ & $\begin{array}{l}\text { No } \\
(\%)\end{array}$ & $\begin{array}{l}\text { Rather } \\
\text { no } \\
(\%)\end{array}$ & $\begin{array}{l}\text { Do not } \\
\text { know } \\
(\%)\end{array}$ & $\begin{array}{l}\text { Rather } \\
\text { yes } \\
(\%)\end{array}$ & $\begin{array}{l}\text { Yes } \\
(\%)\end{array}$ & $\begin{array}{l}\text { Absolutely } \\
\text { yes } \\
(\%)\end{array}$ & $\chi^{2}$ & $\mathrm{p}$-value \\
\hline \multicolumn{11}{|l|}{ Benefits } \\
\hline \multirow[t]{2}{*}{ Increasing property/land value } & Village & 3.8 & 0 & 11.5 & 32.7 & 19.2 & 17.3 & 15.4 & 5.66 & \multirow{2}{*}{0.461} \\
\hline & City & 0 & 1.7 & 10.2 & 23.7 & 23.7 & 15.3 & 25.4 & 8 & \\
\hline \multirow[t]{2}{*}{ Savings on electricity costs } & Village & 1.9 & 5.8 & 11.5 & 48.1 & 7.7 & 7.7 & 17.3 & 3.41 & \multirow{2}{*}{0.755} \\
\hline & City & 1.7 & 8.5 & 5.1 & 44.1 & 15.3 & 10.2 & 15.3 & 5 & \\
\hline \multirow{2}{*}{$\begin{array}{l}\text { Contributing to the economic vitality } \\
\text { of the city }\end{array}$} & Village & 3.8 & 0 & 5.8 & 30.8 & 15.4 & 30.8 & 13.5 & 3.89 & \multirow[b]{2}{*}{0.1424} \\
\hline & City & 1.7 & 0 & 0 & 27.1 & 15.3 & 27.1 & 28.8 & 83 & \\
\hline \multirow{2}{*}{$\begin{array}{l}\text { Reducing expenditure on road } \\
\text { surface repairs }\end{array}$} & Village & 0 & 3.8 & 15.4 & 53.8 & 9.6 & 11.5 & 5.8 & 15.5 & \multirow{2}{*}{0.016} \\
\hline & City & 6.8 & 15.3 & 8.5 & 59.3 & 0 & 5.1 & 5.1 & 45 & \\
\hline \multicolumn{11}{|c|}{ Disservices (problems, hazard costs and expenditures) } \\
\hline \multirow{2}{*}{$\begin{array}{l}\text { Costs of maintaining of mature trees } \\
\text { overwhelm their benefits }\end{array}$} & Village & 17.3 & 15.4 & 26.9 & 30.8 & 3.8 & 3.8 & 1.9 & 13.8 & \multirow{2}{*}{0.032} \\
\hline & City & 33.9 & 27.1 & 10.2 & 13.6 & 5.1 & 8.5 & 1.7 & 05 & \\
\hline \multirow[t]{2}{*}{ Destroying road surface by roots } & Village & 3.8 & 13.5 & 30.8 & 26.9 & 17.3 & 3.8 & 3.8 & 10.8 & \multirow{2}{*}{0.094} \\
\hline & City & 16.9 & 16.9 & 23.7 & 10.2 & 25.4 & 5.1 & 1.7 & 31 & \\
\hline
\end{tabular}


Table 7 (on next page)

Table 7. 
1

2 Table 7. Differences in perception of environmental benefits and disservices between

3 rural and urban residents.

4

\begin{tabular}{|c|c|c|c|c|c|c|c|c|c|c|}
\hline & & $\begin{array}{l}\text { Definit } \\
\text { ely not }\end{array}$ & No & $\begin{array}{l}\text { Rather } \\
\text { no }\end{array}$ & $\begin{array}{l}\text { Do not } \\
\text { know }\end{array}$ & $\begin{array}{l}\text { Rather } \\
\text { yes }\end{array}$ & Yes & $\begin{array}{l}\text { Absolu } \\
\text { tely yes }\end{array}$ & $x^{2}$ & p-value \\
\hline \multicolumn{11}{|l|}{ Benefits } \\
\hline \multirow[t]{2}{*}{ Modifying microclimate } & village & 0 & 1.9 & 1.9 & 1.9 & 7.7 & 42.3 & 44.2 & \multirow{2}{*}{2.240} & \multirow{2}{*}{0.326} \\
\hline & City & 0 & 0 & 0 & 3.4 & 5.1 & 15.3 & 76.3 & & \\
\hline \multirow[t]{2}{*}{ Improving air quality } & village & 0 & 0 & 0 & 3.8 & 5.8 & 30.8 & 59.6 & \multirow{2}{*}{1.134} & \multirow{2}{*}{0.509} \\
\hline & City & 0 & 1.7 & 0 & 1.7 & 10.2 & 23.7 & 62.7 & & \\
\hline \multirow[t]{2}{*}{ Reducing rate of storm water runoff } & village & 1.9 & 3.8 & 7.7 & 40.4 & 11.5 & 15.4 & 19.2 & \multirow{2}{*}{3.288} & \multirow{2}{*}{0.772} \\
\hline & City & 3.4 & 3.4 & 6.8 & 40.7 & 5.1 & 25.4 & 15.3 & & \\
\hline \multirow[t]{2}{*}{ Controlling wind } & village & 3.8 & 1.9 & 3.8 & 7.7 & 25.0 & 38.5 & 19.2 & \multirow{2}{*}{6.333} & \multirow{2}{*}{0.387} \\
\hline & City & 0 & 1.7 & 1.7 & 6.8 & 42.4 & 27.1 & 20.3 & & \\
\hline \multirow[t]{2}{*}{ Reducing solar radiation in summer } & village & 0 & 1.9 & 3.8 & 9.6 & 23.1 & 38.5 & 23.1 & \multirow{2}{*}{2.146} & \multirow{2}{*}{0.342} \\
\hline & city & 0 & 1.7 & 1.7 & 18.6 & 23.7 & 23.7 & 30.5 & & \\
\hline \multirow[t]{2}{*}{ Providing shade on sunny days } & village & 0 & 1.9 & 1.9 & 5.8 & 1.9 & 25.0 & 63.5 & \multirow{2}{*}{2.412} & \multirow{2}{*}{0.878} \\
\hline & city & 1.7 & 1.7 & 0 & 6.8 & 1.7 & 20.3 & 67.8 & & \\
\hline \multirow[t]{2}{*}{ Providing habitat for wildlife } & village & 0 & 0 & 5.8 & 23.1 & 13.5 & 28.8 & 28.8 & \multirow{2}{*}{1.135} & \multirow{2}{*}{0.567} \\
\hline & city & 0 & 1.7 & 1.7 & 16.9 & 11.9 & 30.5 & 37.3 & & \\
\hline \multirow[t]{2}{*}{ Reducing noise } & village & 0 & 0 & 1.9 & 7.7 & 15.4 & 44.2 & 30.8 & \multirow{2}{*}{1.124} & \multirow{2}{*}{0.570} \\
\hline & city & 0 & 0 & 1.7 & 13.6 & 20.3 & 28.8 & 35.6 & & \\
\hline \multicolumn{11}{|c|}{ Disservices (problems, hazard costs and expenditures) } \\
\hline \multirow[t]{2}{*}{ Dropping flowers } & village & 11.5 & 34.6 & 28.8 & 3.8 & 11.5 & 7.7 & 1.9 & \multirow{2}{*}{6.038} & \multirow{2}{*}{0.419} \\
\hline & city & 27.1 & 27.1 & 23.7 & 6.8 & 8.5 & 3.4 & 3.4 & & \\
\hline \multirow[t]{2}{*}{ Dropping leaves } & village & 3.8 & 13.5 & 42.3 & 3.8 & 11.5 & 25.0 & 0 & \multirow{2}{*}{20.142} & 0002 \\
\hline & city & 23.7 & 16.9 & 27.1 & 0 & 18.6 & 8.5 & 5.1 & & \\
\hline Dropping branches and seeds & village & 5.8 & 26.9 & 30.8 & 5.8 & 21.2 & 7.7 & 1.9 & 11868 & 0065 \\
\hline & city & 27.1 & 18.6 & 23.7 & 1.7 & 13.6 & 10.2 & 5.1 & & \\
\hline
\end{tabular}




\section{Table 8 (on next page)}

Table 8. 
1 Table 8. Differences in perception of health benefits and disservices between rural 2 and urban residents.

3

\begin{tabular}{|c|c|c|c|c|c|c|c|c|c|c|}
\hline & & $\begin{array}{l}\text { Definit } \\
\text { ely not }\end{array}$ & No & $\begin{array}{l}\text { Rather } \\
\text { no }\end{array}$ & $\begin{array}{l}\text { Do not } \\
\text { know }\end{array}$ & $\begin{array}{l}\text { Rather } \\
\text { yes }\end{array}$ & Yes & $\begin{array}{l}\text { Absol } \\
\text { utely } \\
\text { yes }\end{array}$ & $\chi^{2}$ & $\begin{array}{l}\mathrm{p}- \\
\text { value }\end{array}$ \\
\hline \multicolumn{11}{|l|}{ Benefits } \\
\hline \multirow[t]{2}{*}{ Creating relaxed psychological states } & village & 0 & 1.9 & 1.9 & 1.9 & 9.6 & 28.8 & 55.8 & \multirow{2}{*}{1.609} & \multirow{2}{*}{0.447} \\
\hline & city & 0 & 1.7 & 0 & 0 & 10.2 & 11.9 & 76.3 & & \\
\hline \multirow[t]{2}{*}{ Reducing stress } & village & 0 & 0 & 1.9 & 3.8 & 11.5 & 32.7 & 50.0 & \multirow{2}{*}{1.054} & \multirow{2}{*}{0.590} \\
\hline & city & 0 & 1.7 & 0 & 8.5 & 3.4 & 18.6 & 67.8 & & \\
\hline \multicolumn{11}{|c|}{ Disservices (problems. hazard costs and expenditures) } \\
\hline \multirow[t]{2}{*}{ Increasing attack by associated insects } & village & 0 & 9.6 & 25.0 & 25.0 & 26.9 & 11.5 & 1.9 & \multirow{2}{*}{11.294} & \multirow{2}{*}{0.080} \\
\hline & city & 15.3 & 18.5 & 13.6 & 30.5 & 18.6 & 10.2 & 3.4 & & \\
\hline
\end{tabular}

4

5 
Table 9 (on next page)

Table 9. 


\section{Table 9. Differences in perception of aesthetic/visual benefits and disservices between} 2 rural and urban residents.

3

\begin{tabular}{|c|c|c|c|c|c|c|c|c|c|c|}
\hline & & $\begin{array}{l}\text { Definitely } \\
\text { not }(\%)\end{array}$ & $\begin{array}{l}\text { No } \\
(\%)\end{array}$ & $\begin{array}{l}\text { Rather } \\
\text { no } \\
(\%) \\
\end{array}$ & $\begin{array}{l}\text { Do not } \\
\text { know } \\
(\%)\end{array}$ & $\begin{array}{l}\text { Rather } \\
\text { yes } \\
(\%) \\
\end{array}$ & $\begin{array}{l}\text { Yes } \\
(\%)\end{array}$ & $\begin{array}{l}\text { Absolutely } \\
\text { yes } \\
(\%) \\
\end{array}$ & $\chi^{2}$ & $\mathrm{p}$-value \\
\hline \multicolumn{11}{|l|}{ Benefits } \\
\hline \multirow[t]{2}{*}{ Looking beautiful while blooming } & village & 0 & 0 & 0 & 1.9 & 5.8 & 23.1 & 69.2 & 1.0 & \multirow{2}{*}{0.590} \\
\hline & city & 0 & 0 & 0 & 1.7 & 5.1 & 20.3 & 72.9 & 54 & \\
\hline \multirow[t]{2}{*}{ Improving scenic quality } & village & 0 & 0 & 0 & 1.9 & 13.5 & 46.2 & 38.5 & 1.1 & \multirow{2}{*}{0.634} \\
\hline & city & 0 & 0 & 1.7 & 1.7 & 8.5 & 35.6 & 52.5 & 27 & \\
\hline \multirow[t]{2}{*}{ Providing privacy } & village & 1.9 & 0 & 15.4 & 11.5 & 21.2 & 28.8 & 30.2 & 12. & \multirow[b]{2}{*}{0.051} \\
\hline & city & 1.7 & 1.7 & 5.1 & 0 & 20.3 & 35.6 & 35.6 & $\begin{array}{l}50 \\
8\end{array}$ & \\
\hline \multirow{2}{*}{$\begin{array}{l}\text { Creating seasonal interest by } \\
\text { highlighting seasonal changes }\end{array}$} & village & 0 & 0 & 1.9 & 0 & 3.8 & 28.8 & 65.4 & 2.8 & \multirow{2}{*}{0.235} \\
\hline & city & 0 & 0 & 0 & 3.4 & 1.7 & 10.2 & 84.7 & 94 & \\
\hline \multirow[t]{2}{*}{ Cover unpleasant views } & village & 0 & 0 & 1.9 & 9.6 & 23.1 & 50.0 & 15.4 & 12. & \multirow[b]{2}{*}{0.056} \\
\hline & city & 1.7 & 1.7 & 1.7 & 10.2 & 16.9 & 27.1 & 40.7 & $\begin{array}{l}26 \\
1\end{array}$ & \\
\hline \multicolumn{11}{|c|}{ Disservices (problems, hazard costs and expenditures) } \\
\hline \multirow{2}{*}{$\begin{array}{l}\text { Drip sap or sticky residue on parked } \\
\text { cars }\end{array}$} & village & 19.2 & 17.3 & 32.7 & 17.3 & 7.7 & 3.8 & 1.9 & 11. & \multirow[b]{2}{*}{0.078} \\
\hline & city & 15.3 & 28.8 & 15.3 & 8.5 & 20.3 & 8.5 & 3.4 & $\begin{array}{l}34 \\
1\end{array}$ & \\
\hline \multirow[t]{2}{*}{ Obscuring good views } & village & 7.7 & 21.2 & 26.9 & 3.8 & 21.2 & 11.5 & 7.7 & 9.0 & \multirow{2}{*}{0.168} \\
\hline & city & 18.6 & 25.4 & 23.7 & 8.5 & 8.5 & 13.6 & 1.7 & 98 & \\
\hline \multirow[t]{2}{*}{ Causing darkness } & village & 7.7 & 13.5 & 32.7 & 9.6 & 28.8 & 5.8 & 1.9 & 6.3 & \multirow{2}{*}{0.387} \\
\hline & city & 8.5 & 27.1 & 30.5 & 10.2 & 15.3 & 8.5 & 0 & 36 & \\
\hline \multirow[t]{2}{*}{ Look ugly if not maintained } & village & 1.9 & 17.3 & 19.2 & 3.8 & 36.5 & 19.2 & 1.9 & 15. & \multirow[b]{2}{*}{0.019} \\
\hline & city & 22.0 & 22.0 & 13.6 & 6.8 & 20.3 & 10.2 & 5.1 & $\begin{array}{l}10 \\
1\end{array}$ & \\
\hline
\end{tabular}


Table $\mathbf{1 0}$ (on next page)

Table 10. 


\section{Table 10. Differences between urban and rural parents with regard to approaches to} 2 children's play in natural surroundings.

3

\begin{tabular}{|c|c|c|c|c|c|c|c|c|c|c|}
\hline & & $\begin{array}{l}\text { Definitely } \\
\text { not }\end{array}$ & No & $\begin{array}{l}\text { Rather } \\
\text { no }\end{array}$ & $\begin{array}{l}\text { Do not } \\
\text { know }\end{array}$ & $\begin{array}{l}\text { Rather } \\
\text { yes }\end{array}$ & Yes & $\begin{array}{l}\text { Absolutely } \\
\text { yes }\end{array}$ & $\chi^{2}$ & p-value \\
\hline \multirow[t]{2}{*}{ Improving physical health } & village & 0 & 1.9 & 0 & 13.5 & 15.4 & 32.7 & 36.5 & 6.86 & \multirow{2}{*}{0.333} \\
\hline & city & 5.1 & 3.4 & 5.1 & 6.8 & 13.6 & 30.5 & 35.6 & 6 & \\
\hline \multirow[t]{2}{*}{ Improving psychological health } & village & 0 & 0 & 0 & 3.8 & 13.5 & 28.8 & 53.8 & 4.10 & \multirow{2}{*}{0.128} \\
\hline & city & 0 & 1.7 & 5.1 & 1.7 & 11.9 & 22.0 & 57.6 & 9 & \\
\hline \multirow[t]{2}{*}{ Improving children's development } & village & 0 & 0 & 0 & 5.8 & 21.2 & 34.6 & 38.5 & 0.94 & \multirow{2}{*}{0.6225} \\
\hline & city & 0 & 0 & 1.7 & 6.8 & 8.5 & 23.7 & 59.3 & 79 & \\
\hline \multirow{2}{*}{$\begin{array}{l}\text { Causing danger on playgrounds } \\
\text { (and therefore should be removed) }\end{array}$} & village & 15.4 & 30.8 & 21.2 & 5.8 & 13.5 & 7.7 & 5.8 & 17.9 & \multirow{2}{*}{0.006} \\
\hline & city & 42.4 & 28.8 & 11.9 & 10.2 & 1.7 & 5.1 & 0 & 5 & \\
\hline \multirow{2}{*}{$\begin{array}{l}\text { Breakable branches are a threat to } \\
\text { safety }\end{array}$} & village & 3.8 & 23.1 & 21.2 & 11.5 & 28.8 & 11.5 & 0 & 7.15 & \multirow{2}{*}{0.307} \\
\hline & city & 10.2 & 23.7 & 28.8 & 15.3 & 13.6 & 6.8 & 1.7 & 7 & \\
\hline \multirow[t]{2}{*}{ Increase allergy attacks } & village & 3.8 & 5.8 & 5.8 & 26.9 & 30.8 & 25.0 & 1.9 & 9.47 & \multirow{2}{*}{0.148} \\
\hline & city & 3.4 & 11.9 & 15.3 & 13.6 & 25.4 & 20.3 & 10.2 & 6 & \\
\hline \multirow{3}{*}{$\begin{array}{l}\text { Do you try to protect children from } \\
\text { trees (prohibition of climbing trees, } \\
\text { touching rotten parts, playing with } \\
\text { leaves, branches)? }\end{array}$} & village & 3.8 & 23.1 & 23.1 & 7.7 & 9.6 & 21.2 & 11.5 & & \multirow{3}{*}{0.0504} \\
\hline & & & & & & & & & 12.5 & \\
\hline & city & 23.7 & 20.3 & 18.6 & 3.4 & 8.5 & 8.5 & 16.9 & 69 & \\
\hline
\end{tabular}

\section{4}

5 